\title{
Isolation of antibacterial response genes from the dung beetle Copris tripartitus (Coleoptera: Scarabaeidae) immunized with Escherichia coli
}

\author{
Jae-Sam HWANG ${ }^{1}$, Yeon-Ju KIM ${ }^{1}$, Hea-Son BANG ${ }^{1}$, Eun-Young YUN ${ }^{1}$, Young-Tae KIM ${ }^{2}$, Seong-Ryul KIM ${ }^{1}$, \\ KwAN-Ho PARK ${ }^{1}$, NAM-Soon KIM ${ }^{3}$, IKSOo KIM ${ }^{4}$, SEOK-Jo HwAng ${ }^{1}$ and JAE-PIL JEON ${ }^{5}$ \\ ${ }^{1}$ National Institute of Agricultural Science and Technology, RDA, Suwon 441-100, South Korea; e-mail: hwangjs@rda.go.kr \\ ${ }^{2}$ National Institute of Agricultural Biotechnology RDA, Suwon 441-100, South Korea \\ ${ }^{3}$ Genome Research Center, Korea Research Institute of Bioscience and Biotechnology, Taejon 305-333, South Korea \\ ${ }^{4}$ College of Agriculture \& Life science, Chonnam National University, Gwangju 500-757, South Korea \\ ${ }^{5}$ Korea National Institute of Health, Seoul 136-713, South Korea
}

Key words. Antibacterial gene, dung beetle, HSP70

\begin{abstract}
Dot blot hybridization of total RNA from normal and bacteria-injected larvae of the dung beetle Copris tripartitus identified $13 \mathrm{cDNA}$ clones that seem to be associated with the immune response. A cDNA encoding a dung beetle homolog of the heat shock protein HSP70 (CTHSP70) was characterized by full-length sequencing and expression pattern analysis. CTHSP70 was upregulated $4 \mathrm{~h}$ after bacterial injection, reached maximum level after $8 \mathrm{~h}$, and declined gradually after $16 \mathrm{~h}$. Our data suggest that CTHSP70 and another 12 genes are involved in the anti-microbial defense that is particularly important for dung beetle larvae living in pathogen-rich conditions.
\end{abstract}

\section{INTRODUCTION}

To defend themselves against infection by a variety of bacteria, fungi and parasites, insects have evolved several efficient defense mechanisms, including the production of antimicrobial compounds. So far, more than 200 antibacterial peptides have been identified in insects. These peptides are known to play important roles in the humoral defense reaction (Hultmark, 2003; Lemaitre, 2004; Hoffmann, 2003; Hoffman et al., 1999; Engstrom, 1999; Garcia-Orozco, 2005). Humoral reactions include synthesis of antimicrobial proteins, which are secreted into the haemolymph, and proteolytic cascades leading to localized coagulation (Hoffman, 1995). The insect antibacterial peptides are classified into three groups, which are linear alpha-helical peptides devoid of cysteine residues, peptides in which proline and/or glycine residues are over-represented, and cysteine-rich peptides with cysteine established $\alpha-\beta$ motif (Bulet et al., 1999). Copris tripartitus spends a lot of time in dung, which contains an abundance of pathogens. The larvae feed on the fungi, decaying organic matter, dung and other organic materials in dung balls. Thus, it is likely that $C$. tripartitus defends itself against invading pathogens by means of antimicrobial compounds. Therefore, the purpose of the present study was to isolate and identify immune related genes in the dung beetle, $C$. tripartitus. In this study, we cloned immunerelated genes differentially expressed in control and immunized larvae, and detected the time course of expression using Northern blot.

\section{MATERIAL AND METHODS}

\section{Immunization}

To induce antibacterial peptides, the Copris tripartitus larvae were cooled on ice and individually injected with $50 \mu \mathrm{l}$ of $E$. coli JM109 $\left(5 \times 10^{5}\right.$ cells $)$ suspended in physiological saline $(150 \mathrm{mM} \mathrm{NaCl} / 5 \mathrm{mM} \mathrm{KCL})$. Larvae were analyzed after $0-24 \mathrm{~h}$.

\section{Construction of the full-length enriched cDNA library}

cDNA library from larvae of $C$. tripartitus immunized with $E$. coli was constructed using a modification of Maruyama and Sugano's method (Maruyama \& Sugano, 1994). Briefly, $100 \mu \mathrm{g}$ of total RNA was treated with 3 units of bacterial alkaline phosphatase (TaKaRa, Shiga, Japan) in $100 \mu \mathrm{l}$ of $100 \mathrm{mM}$ Tris- $\mathrm{HCl}$ (pH 7.5), 2 mM DTT and 80 units of RNasin (Promega, Madison, WI, USA) at $37^{\circ} \mathrm{C}$ for $60 \mathrm{~min}$. After phenol extraction and ethanol precipitation, the total RNA was treated with 100 units of tobacco acid pyrophosphatase (Waco, Tokyo, Japan) in 100 l $50 \mathrm{mM}$ sodium acetate (pH 5.5), $5 \mathrm{mM}$ EDTA, $10 \mathrm{mM}$ 2-mercaptoethanol and 80 units RNasin at $37^{\circ} \mathrm{C}$ for $60 \mathrm{~min}$. The pretreated total RNA was then ligated with $0.4 \mu \mathrm{g}$ of 5-oligoribonucleotide (5-oligo: 5-AGC AUC GAG UCG GCCC UUG UUG GCC UAC UGG-3) using 250 units of RNA ligase (TaKaRa) in $100 \mu \mathrm{l}$ of $50 \mathrm{mM}$ Tris- $\mathrm{HCl}(\mathrm{pH} 7.5), 5 \mathrm{mM} \mathrm{MgCl}_{2}$, $5 \mathrm{mM}$ 2-mercaptoethanol, $0.5 \mathrm{mM}$ ATP, 25\% PEG 8000 and 100 units of RNasin at $20^{\circ} \mathrm{C}$ for $3 \mathrm{~h}$. After completing these oligo-capping reactions, mRNA was isolated using a commercial kit, QIAGEN Oligotex ${ }^{\mathrm{TM}}$ (Qiagen, Hilden, Germany). The synthesis of first-strand cDNA from the purified mRNA, and the cDNA amplification were performed as described by Maruyama \& Sugano (1994). The amplified PCR products were digested with SfiI, and cDNAs longer than $1.3 \mathrm{~kb}$ were ligated into DraIII-digested pCNS-D2 in an orientation-defined manner. The pCNS-D2 vector contains 5 EcoRI-DraIII-EcoRV-DraIII sites at multi cloning sites, which was achieved by modifying the pCNS vector (GenBank Accession no. AF416744). The ligated cDNA was transferred into E. coli Top10F' (Invitrogen, Carlsbad, CA, USA) by electroporation (Gene Pulser II, BioRad, Hercules, CA, USA).

\section{Dot blot anlalysis and DNA sequencing}

A total of 1862 random cDNA clones were arrayed onto a Hybond-N membrane (Amersham Biosciences, Uppsala, Sweden) using a 96-well format dot blotter (Bio-Rad). Two cDNA 

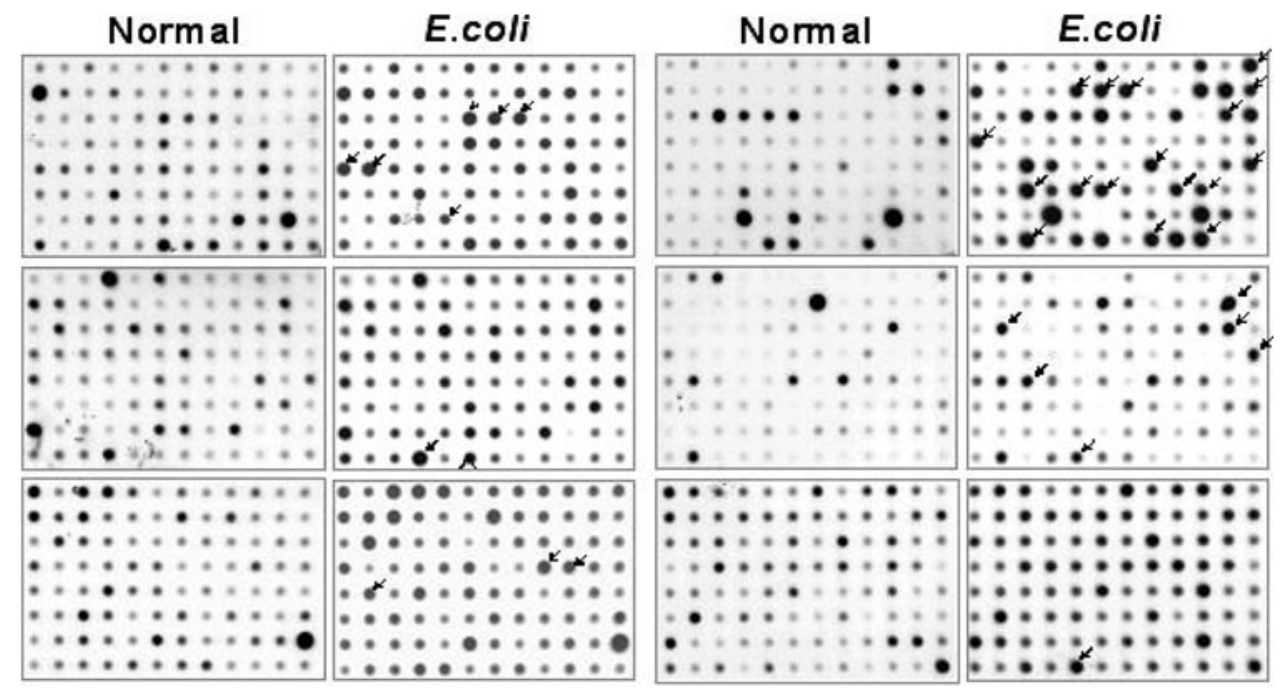

Fig. 1. Randomly selected 1,862 genes from cDNA library of Copris tripartitus larvae, spotted onto nylon membranes and hybridized with $\left[\alpha-{ }^{32} \mathrm{P}\right] \mathrm{dCTP}-l$ labelled RNA samples from normal and $E$. coli immunized larvae. Arrows indicate differently expressed clones in E. coli immunized larvae. Among the total of 1,862 EST clones, 13 cDNA transcripts were expressed differentially in $E$. coli immunized larvae.

probes labelled with $\left[\alpha{ }^{32} \mathrm{P}\right] \mathrm{dCTP}$ were generated by reverse transcription of $0.5-1.0 \mu$ gpoly $(\mathrm{A})^{+}$RNA samples prepared from the normal and the immunized larvae. Probes were mixed with hybridization solution containing $50 \%$ formamide, $5 \times$ SSC, $10 \times$ Denhardt's solution $(0.2 \%$ each of bovine serum albumin, ficoll and polyvinylpyrrolidone), $25 \mu \mathrm{g} / \mathrm{ml}$ sonicated salmon sperm DNA, and $50 \mathrm{mM}$ sodium phosphate $(\mathrm{pH} 7.0)$. Hybridization was for $3 \mathrm{~h}$ at $65^{\circ} \mathrm{C}$. After hybridization the membranes were washed in buffers of increasing stringency, from 2 $\times$ SSC containing $0.1 \%$ SDS to $0.1 \times$ SSC containing $0.1 \%$ SDS, $30 \mathrm{~min}$ in each and then exposed to X-ray film (Agfa, Wiesbaden, Germany) for 1 or 3 days at $-70^{\circ} \mathrm{C}$. cDNA clones selected by the dot blot analysis were sequenced using the $\mathrm{ABI}$ 310 Automated Sequencer (Applied Biosystems, Foster City, CA, USA). The sequences were analyzed with the BLASTX program and protein database (http://www.ncbi.nlm.nih.gov/ BLAST/) of the National Center for Biotechnology Information (NCBI)

\section{RACE (rapid amplification of cDNA ends)-PCR}

The 5'-end and 3'-end RACE-PCR were performed using Marathon cDNA Amplification Kit (Clontech, Mauntain View, CA, USA) according to the manufacture's protocol. Briefly, gene-specific primers were designed from the partial cDNA sequence of the CTHSP70. These primers were used in conjunction with the anchor primer API (Clontech) to amplify the $5^{\prime}$ and $3^{\prime}$ ends of the DDC gene from cDNA. PCR was performed for 30 cycles of $30 \mathrm{~s}$ at $94^{\circ} \mathrm{C}, 30 \mathrm{~s}$ at $60^{\circ} \mathrm{C}$, and $1 \mathrm{~min}$ at $72^{\circ} \mathrm{C}$, followed by a $5 \mathrm{~min}$ final extension step at $72^{\circ} \mathrm{C}$. PCR products were isolated and subcloned into the pGEM T Easy Vector (Promega) and sequenced by the dideoxy-mediated chain termination method using an ABI 310 Automated Sequencer.

\section{Northern Blot Analysis}

Total RNA was extracted with a Trizol reagent (Life technologies, Inc., Gaithersburg, MD, USA) from the whole larvae $0,4,8,16$, and $24 \mathrm{~h}$ after $E$. coli injection and quantified by ultraviolet spectroscopy. Aliquots of $10 \mu \mathrm{g}$ total RNA were fractionated on $1 \%$ agarose $/ 6.7 \%$ formaldehyde gels and blotted onto nylon membranes (Schleicher \& Schwell BioScience, Sanford, ME, USA) using $20 \times$ SSC buffer. Membranes were hybridized with cDNA probes labelled with $\left[\alpha-{ }^{32} \mathrm{P}\right] \mathrm{dCTP}$ using a random primer labelling kit (Stratagene, La Jolla, CA, USA). Hybridization was performed for $3 \mathrm{~h}$ at $65^{\circ} \mathrm{C}$ in the ExpressedHyb hybridization solution, according to the manufacturer's instruction (Clontech). Membranes were subsequently exposed to Kodak BIOMAX film (Eastman Kodak Co., Rochester, NY, USA) at $70^{\circ} \mathrm{C}$. As an internal marker, $28 \mathrm{~S}$ rRNA was visualized by ethidium bromide staining.

\section{RESULTS AND DISCUSSION}

As an initial step in the search for antibacterial peptides in Copris tripartitus, a full-length cDNA library was constructed from whole larvae of $C$. tripartitus immunized with $E$. coli. The cDNA library was plated out on LB-agarose plates covering an estimated 100,000 clones expressed in the library, and then 1,862 randomly selected cDNA clones were selected randomly from the cDNA library. Amplified PCR products were prepared and blotted onto duplicate nylon membranes. Screening was performed by differential hybridization with two types of $\left[\alpha-{ }^{32} \mathrm{P}\right] \mathrm{dCTP}-\mathrm{labeled}$ total cDNA probes synthesized from the normal and the immunized larvae.

Differential expression profiles of 1,862 clones (Fig. 1) revealed $13 \mathrm{cDNAs}$ that were expressed preferentially or exclusively in the immunized larvae. Sequences of these cDNAs were determined by single-run partial sequencing and compared with the data in public databases. Seven cDNAs represented well known genes of the immune response: defensin, heat shock protein 70 , peptidoglycan recognition protein, actin superfamily AT14584P, calreticulin, catalase, and transferrin. Each of these differentially expressed genes exhibited a significant protein sequence identity to the corresponding genes known from insects (Table 1). The remaining 6 cDNAs were functionally unidentified.

Insect defensins are generally cationic peptides composed of 34-46 residues with molecular mass ranging from 2 6 kDa. Initially discovered in Diptera (Matsuyama \& Natori, 1988), defensins have since been described in various insects of the Neoptera cohort. Most of them act against a broad spectrum of Gram-positive bacteria and have little effect on Gram-negative bacteria and fungi (Dimarcq et al., 1994). HSP70 can be induced by various chemicals and biological stresses such as heat shock, oxidative stress, heavy metals, and amino acid ana- 
1 GTTATTCGAGCACATACCTTCGAACGGTGAGGACGTACCGCAACATTTCGTGTCCGATTTTTTTTCTAGAAATTTCCACGTTTTTACACA CACAAGAAAGAGATGGCCAAGGCTCCGGCGGTCGGTATCGATTTGGGCACGACGTATTCGTGCGTCGGAGTTTTCCAACATGGAAAGGTC

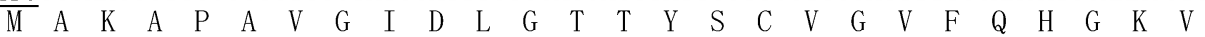

GAAATTATTGCTAATGACCAAGGTAACAGAACTACGCCCTCTTACGTCGCGTTCACGGACACGGAACGTCTCATCGGAGATGCCGCAAAG $\begin{array}{lllllllllllllllllllllllllllllll}\text { E } & \text { I } & \text { I } & \text { A } & \text { N } & \text { D } & \text { Q } & G & \text { N } & \text { R } & \text { T } & \text { T } & \text { P } & \text { S } & \text { Y } & \text { V } & \text { A } & \text { F } & \text { T } & \text { D } & \text { T } & \text { E } & \text { R } & \text { L } & \text { I } & \text { G } & \text { D } & \text { A } & \text { A } & \text { K }\end{array}$

AACCAAGTCGCCATGAATCCAAATAACACTATTTTCGATGCAAAAAGATTGATTGGTCGCAGATTTGATGACCATGCCGTACAAGCTGAT $\begin{array}{llllllllllllllllllllllllllllllll}N & Q & V & A & M & N & P & N & N & T & I & F & D & A & K & R & L & I & G & R & R & F & D & D & H & A & V & Q & A & D\end{array}$

ATGAAACACTGGCCCTTCGATGTCATCAACGATGGGGGCAAACCTAAAATTAAAGTAGAATACAAAGGGGAGGTCAAAACGTTCTATCCC $\begin{array}{lllllllllllllllllllllllllllllll}M & K & H & W & P & F & D & V & I & N & D & G & G & K & P & K & I & K & V & E & Y & K & G & E & V & K & T & F & Y & P\end{array}$

GAGGAAGTGAGTTCTATGGTTTTAACGAAAATGAAAGAGACAGCTGAAGCGTACCTAGGGAAGTCCGTAGTGAACGCCGTCATTACCGTA

541 CCGGCCTATTTCAACGATTCACAACGTCAAGCGACGAAAGATGCCGGGACAATTGCGGGACTTCAGGTTTTACGTATCATCAACGAACCA $\begin{array}{lllllllllllllllllllllllllllllll}181 & \mathrm{P} & \mathrm{A} & \mathrm{Y} & \mathrm{F} & \mathrm{N} & \mathrm{D} & \mathrm{S} & \mathrm{Q} & \mathrm{R} & \mathrm{Q} & \mathrm{A} & \mathrm{T} & \mathrm{K} & \mathrm{D} & \mathrm{A} & \mathrm{G} & \mathrm{T} & \mathrm{I} & \mathrm{A} & \mathrm{G} & \mathrm{L} & \mathrm{Q} & \mathrm{V} & \mathrm{L} & \mathrm{R} & \mathrm{I} & \mathrm{I} & \mathrm{N} & \mathrm{E} & \mathrm{P}\end{array}$

631 ACAGCGGCTGCTATTGCGTACGGTTTAGACAAAAAGGGAGTGGGAGAGAGGAACGTATTGATTTTCGACTTGGGTGGTGGAACTTTTGAT

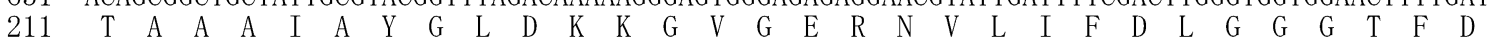

721 GTATCAATTTTGACCATTGAAGATGGTATTTTCGAGGTCAAATCGACAGCTGGCGACACACACTTGGGTGGGGAAGATTTTGATAATCGC

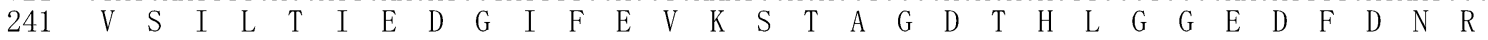

811 ATGGTAAACCATTTCGTTCAGGAATTCAAGAGGAAGTACAAGAAGGATTTGACTTCTAACAAACGCGCGTTGCGCCGTCTCCGAACATCT $\begin{array}{llllllllllllllllllllllllllllllll}271 & M & V & N & H & F & V & Q & E & F & K & R & K & Y & K & K & D & L & T & S & N & K & R & A & L & R & R & L & R & T & S\end{array}$

901 TGCGAAAGAGCGAAACGTACTCTCTCATCATCCACTCAGGCGAGCATCGAAATTGACTCACTGTACGAGGGTATCGACTTTTACACTTCC $\begin{array}{lllllllllllllllllllllllllllllllll}301 & \mathrm{C} & \mathrm{E} & \mathrm{R} & \mathrm{A} & \mathrm{K} & \mathrm{R} & \mathrm{T} & \mathrm{L} & \mathrm{S} & \mathrm{S} & \mathrm{S} & \mathrm{T} & \mathrm{Q} & \mathrm{A} & \mathrm{S} & \mathrm{I} & \mathrm{E} & \mathrm{I} & \mathrm{D} & \mathrm{S} & \mathrm{L} & \mathrm{Y} & \mathrm{E} & \mathrm{G} & \mathrm{I} & \mathrm{D} & \mathrm{F} & \mathrm{Y} & \mathrm{T} & \mathrm{S}\end{array}$

991 ATTACTCGTGCTCGTTTCGAAGAGTTAAATGCAGATCTATTCCGCTCCACCATGGAACCTGTGGAGAAATCTCTTCGTGATGCTAAAATG $\begin{array}{llllllllllllllllllllllllllllllll}331 & \mathrm{I} & \mathrm{T} & \mathrm{R} & \mathrm{A} & \mathrm{R} & \mathrm{F} & \mathrm{E} & \mathrm{E} & \mathrm{L} & \mathrm{N} & \mathrm{A} & \mathrm{D} & \mathrm{L} & \mathrm{F} & \mathrm{R} & \mathrm{S} & \mathrm{T} & \mathrm{M} & \mathrm{E} & \mathrm{P} & \mathrm{V} & \mathrm{E} & \mathrm{K} & \mathrm{S} & \mathrm{L} & \mathrm{R} & \mathrm{D} & \mathrm{A} & \mathrm{K} & \mathrm{M}\end{array}$

1081 GACAAAGCACAGATTCACGATATTGTGTTGGTTGGCGGATCAACCCGTATCCCAAAAGTTCAAAAACTCCTTCAAGATTTCTTTAACGGA $\begin{array}{lllllllllllllllllllllllllllllll}361 & \mathrm{D} & \mathrm{K} & \mathrm{A} & \mathrm{Q} & \mathrm{I} & \mathrm{H} & \mathrm{D} & \mathrm{I} & \mathrm{V} & \mathrm{L} & \mathrm{V} & \mathrm{G} & \mathrm{G} & \mathrm{S} & \mathrm{T} & \mathrm{R} & \mathrm{I} & \mathrm{P} & \mathrm{K} & \mathrm{V} & \mathrm{Q} & \mathrm{K} & \mathrm{L} & \mathrm{L} & \mathrm{Q} & \mathrm{D} & \mathrm{F} & \mathrm{F} & \mathrm{N} & \mathrm{G}\end{array}$

1171 AAGGAATTGAATAAGTCCATCAACCCTGATGAGGCTGTAGCTTATGGCGCTGCCGTGCAAGCGGCTATTTTACACGGTGATAAATCTGAA $\begin{array}{llllllllllllllllllllllllllllllll}391 & \mathrm{~K} & \mathrm{E} & \mathrm{L} & \mathrm{N} & \mathrm{K} & \mathrm{S} & \mathrm{I} & \mathrm{N} & \mathrm{P} & \mathrm{D} & \mathrm{E} & \mathrm{A} & \mathrm{V} & \mathrm{A} & \mathrm{Y} & \mathrm{G} & \mathrm{A} & \mathrm{A} & \mathrm{V} & \mathrm{Q} & \mathrm{A} & \mathrm{A} & \mathrm{I} & \mathrm{L} & \mathrm{H} & \mathrm{G} & \mathrm{D} & \mathrm{K} & \mathrm{S} & \mathrm{E}\end{array}$

1261 GAGGTTCAGGATTTGCTGCTTTTGGACGCTACGCCGTTATCGTTGGGAATTGAAACCGCCGGTGGTGTGATGACGGCTCTCATCAAACGG

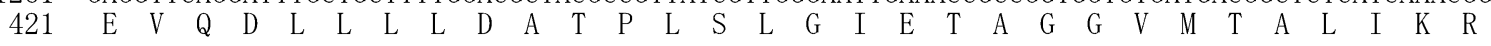

1351 AATACTACGATCCCTACGAAACAGACGCAGACGTTCACAACATATTCTGATAACCAACCTGGAGTGCTTATACAAGTTTATGAAGGCGAA $\begin{array}{lllllllllllllllllllllllllllllll}451 & \mathrm{~N} & \mathrm{~T} & \mathrm{~T} & \mathrm{I} & \mathrm{P} & \mathrm{T} & \mathrm{K} & \mathrm{Q} & \mathrm{T} & \mathrm{Q} & \mathrm{T} & \mathrm{F} & \mathrm{T} & \mathrm{T} & \mathrm{Y} & \mathrm{S} & \mathrm{D} & \mathrm{N} & \mathrm{Q} & \mathrm{P} & \mathrm{G} & \mathrm{V} & \mathrm{L} & \mathrm{I} & \mathrm{Q} & \mathrm{V} & \mathrm{Y} & \mathrm{E} & \mathrm{G} & \mathrm{E}\end{array}$

1441 AGAGCTATGACAAAAGATAATAACCTTTTGGGAAAATTCGAACTTACGGGAATTCCACCAGCACCGAGAGGTGTCCCTCAAATTGAAGTA $\begin{array}{ccccccccccccccccccccccccccccccc}481 & \mathrm{R} & \mathrm{A} & \mathrm{M} & \mathrm{T} & \mathrm{K} & \mathrm{D} & \mathrm{N} & \mathrm{N} & \mathrm{L} & \mathrm{L} & \mathrm{G} & \mathrm{K} & \mathrm{F} & \mathrm{E} & \mathrm{L} & \mathrm{T} & \mathrm{G} & \mathrm{I} & \mathrm{P} & \mathrm{P} & \mathrm{A} & \mathrm{P} & \mathrm{R} & \mathrm{G} & \mathrm{V} & \mathrm{P} & \mathrm{Q} & \mathrm{I} & \mathrm{E} & \mathrm{V}\end{array}$

1531 ACCTTTGACATTGACGCCAACGGTATCCTGAACGTAACCGCCATTGAAAAATCCACTAACAAAGAAAACAAAATTACCATCACCAACGAC

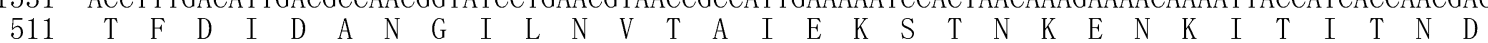

1621 AAGGGACGTCTCAGCAAGGAAGAAATTGAACGTATGGTTAATGATGCTGAGAAGTACCGAAGCGAAGATGAGAAACAAAGGAACACTATT $\begin{array}{lllllllllllllllllllllllllllllll}541 & \mathrm{~K} & G & \mathrm{R} & \mathrm{L} & \mathrm{S} & \mathrm{K} & \mathrm{E} & \mathrm{E} & \mathrm{I} & \mathrm{E} & \mathrm{R} & \mathrm{M} & \mathrm{V} & \mathrm{N} & \mathrm{D} & \mathrm{A} & \mathrm{E} & \mathrm{K} & \mathrm{Y} & \mathrm{R} & \mathrm{S} & \mathrm{E} & \mathrm{D} & \mathrm{E} & \mathrm{K} & \mathrm{Q} & \mathrm{R} & \mathrm{N} & \mathrm{T} & \mathrm{I}\end{array}$

1711 ACAGCAAAGAACGCCCTTGAATCCTATTGCTTCAATATCAAAGCAACTATGGAGGATGAAAAAATCAAGGATAAAATCACAGAGTCCGAT $\begin{array}{lllllllllllllllllllllllllllllllll}571 & \mathrm{~T} & \mathrm{~A} & \mathrm{~K} & \mathrm{~N} & \mathrm{~A} & \mathrm{~L} & \mathrm{E} & \mathrm{S} & \mathrm{Y} & \mathrm{C} & \mathrm{F} & \mathrm{N} & \mathrm{I} & \mathrm{K} & \mathrm{A} & \mathrm{T} & \mathrm{M} & \mathrm{E} & \mathrm{D} & \mathrm{E} & \mathrm{K} & \mathrm{I} & \mathrm{K} & \mathrm{D} & \mathrm{K} & \mathrm{I} & \mathrm{T} & \mathrm{E} & \mathrm{S} & \mathrm{D}\end{array}$

1801 AAAACCACCGTTATGGAAAAATGTAATGAAGTTATCGCTTGGTTAGATGCAAATCAACTGGCCGATAAAGAAGAGTACGAACACAAACAG $\begin{array}{llllllllllllllllllllllllllllllll}601 & \mathrm{~K} & \mathrm{~T} & \mathrm{~T} & \mathrm{~V} & \mathrm{M} & \mathrm{E} & \mathrm{K} & \mathrm{C} & \mathrm{N} & \mathrm{E} & \mathrm{V} & \mathrm{I} & \mathrm{A} & \mathrm{W} & \mathrm{L} & \mathrm{D} & \mathrm{A} & \mathrm{N} & \mathrm{Q} & \mathrm{L} & \mathrm{A} & \mathrm{D} & \mathrm{K} & \mathrm{E} & \mathrm{E} & \mathrm{Y} & \mathrm{E} & \mathrm{H} & \mathrm{K} & \mathrm{Q}\end{array}$

1891 AAAGAACTGGAAGGTGTTTGCAATCCCATCATTACGAAATTCTATCAGGCCGCCGGTGGAGCTCCTCCAGGAGGTATGCCAGGTTTCCCA

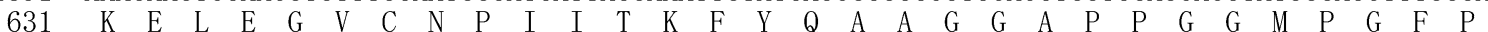

1981 GGTGGAGCAGGGGCAGCTCCTGGAGGTCCAGCACCAGGCGCTGGAAATACTGGACCAACCATCGAGGAAGTAGATTAAATTTGTTTCTGT

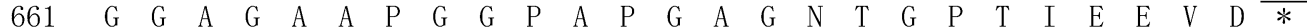

2071 TTTATAACCATTCCATTTTTAAAAAACCAGTATTATTTCAGACAAAACTTTTTTTTTTTTTAATTTAAAGCTGATTTTTGTAATGCCGCC 2161 AAAGATATTTCAATTATTTTCAATATTCCTTTCATATTTCTTCTGAAATATTTCTTTTTTTGTTTTGATTTATTCTGGGGTATCTGTAGT 2251 AGTTTGGAGATTTTTTCTTGTCGGTTGCATAATGAAACTTTGAAAAGTCTAATAAAGATACAAATTACCCTGAAAAAAAAAAAAAAAAAA

2341 AAAAAAAAAAAAA

Fig. 2. Nucleotide and deduced amino acid sequences of the Cthsp 70 gene isolated from Copris tripartitus. The predicted amino acid sequence (single-letter abbreviation) is shown below the nucleotide within the open reading frame. Codons for initiation, termination, polyadenylation, and poly(A) tail are in bold. The asterisk denotes a stop codon. 
TABLE 1. Differentially expressed genes in E. coli immunized larvae.

\begin{tabular}{|c|c|c|c|c|c|c|}
\hline Representative clones & Putative indentification & Species & Gene bank no. & Identity (\%) & Score & E-value \\
\hline $\mathrm{SC} 1$ & NI & & & & & \\
\hline $\mathrm{SC} 2$ & Defensin-A & Anomala cuprea & BAD77966.1 & 62 & 107 & $1.00 \mathrm{E}-22$ \\
\hline $\mathrm{SC} 3$ & Heat shock protein 70 & Locusta migratoria & AAP57537.3 & 92 & 317 & $3.00 \mathrm{E}-85$ \\
\hline SC6 & NI & & & & & \\
\hline $\mathrm{SC} 2-5$ & NI & & & & & \\
\hline $\mathrm{SC} 3-5$ & Peptidoglycan recognition SC2 & Drosophila melanogaster & CAD89185.1 & 45 & 161 & $2.00 \mathrm{E}-38$ \\
\hline SC8-5 & NI & & & & & \\
\hline $\mathrm{SC} 10-5$ & AT14584p & Drosophila melanogaster & AAV37037.1 & 95 & 244 & $1.00 \mathrm{E}-63$ \\
\hline $\mathrm{SC} 11-5$ & Calreticulin & Bombyx mori & AAP50845.1 & 77 & 196 & $6.00 \mathrm{E}-49$ \\
\hline $\mathrm{SC} 14-5$ & NI & & & & & \\
\hline SC29-5 & Catalase & Apis mellifera ligustica & AAN76688.1 & 72 & 220 & $2.00 \mathrm{E}-56$ \\
\hline $\mathrm{SC} 31-5$ & Transferrin & Apriona germari & AAW70172.1 & 69 & 126 & $3.00 \mathrm{E}-28$ \\
\hline SC33-5 & NI & & & & & \\
\hline
\end{tabular}

NI - not identified.

logues, inhibitors of energy for energy metabolism, UV and irradiation, viral and bacterial infections, parasitism, alcohol, crowding, and inflammation (Lindquist \& Craig, 1988; Hartl, 1996; Morimoto et al., 1990, 1992; Abe et al., 1995; Fukamachi et al., 1998; Wagner et al., 1999; Sierra-River et al., 1993; Hatayama et al., 1993; Goodman \& Blank, 1998; Gething \& Sambrook, 1992; Sørensen \& Loeschcke, 2001). Peptidoglycan recognition proteins are evolutionarily conserved molecules that are structurally related to bacterial amidases. Peptidodoglycans occur in the cell walls of almost all bacteria and in many insects induce strong antibacterial responses that include activation of phenoloxidase leading to melanin formation in infected wounds. Recently, peptidoglycan recognition proteins, $\mathrm{SC} 1$ and $\mathrm{SC} 2$, were reported as downregulators in the Drosophila immune response (Bischoff et al., 2006). In insects, calreticulin is an early stage capsulation protein involved in non-self recognition in the cellular defense reaction (Zhang et al., 2006). Catalase is one of the regulatory enzymes and facilitates the degradation of hydrogen peroxide to oxygen and water (Collins et al., 2004). Insect transferrin is considered to be an infection-inducible gene (Yoshiga et al., 1997, Thompson et al., 2003) and has been implicated in innate immunity to microbial infection by means sequestering iron.

\section{E. coli}

\begin{tabular}{|c|c|c|c|c|}
\hline 0 & 4 & 8 & 24 & \\
\hline & & & $8=$ & CTHSP70 \\
\hline
\end{tabular}

Fig. 3. Time course gene expression analysis of Cthsp70 using Northern hybridization. Copris tripartitus larvae were injected with $50 \mu \mathrm{l}$ of $E$. coli $\mathrm{JM} 109\left(5 \times 10^{5}\right.$ cells $)$ suspended in physiological saline $(150 \mathrm{mM} \mathrm{NaCl} / 5 \mathrm{mM} \mathrm{KCl})$. Larvae were kept for $0,4,8,16$, and 24 h. $10 \mu \mathrm{g}$ aliquots of total RNA were resolved on formaldehyde containing agarose gels and blotted onto nitrocellulose membranes. The probe was labelled with $\left[\alpha{ }^{-32} \mathrm{P}\right] \mathrm{dCTP}$. As internal marker, 28S rRNA was stained with ethidium bromide.
According to the aforementioned reports, HSP70 is known to be induced in response to various biological stresses including viral and bacterial infections. CTHSP70, a dung beetle homologue of HSP70, was selected for further studies because of the infection-inducible genes identified in C. tripartitus HSP70 is the most likely to be a potential antimicrobial. We determined the nucleotide sequence of the CTHSP70 cDNA encoding the heat shock protein homolog of $C$. tripartitus.

In order to obtain the full cDNA sequence of CTHSP70, we performed 5'- and 3'-RACE-PCR. The full cDNA sequence of 2,354 bases contains initiation codon ATG in position 103 and the stop codon TAA at 2059 and encodes a protein of 652 amino acids (Fig. 2). Blast analysis of CTHSP70 revealed close matches with other known HSP70. The deduced amino acid sequence of CTHSP70 was highly similar to HSP70 in invertebrate and vertebrates, plants and yeasts (data not shown). The similarity was more than $70 \%$ in all matches identified from vertebrates and invertebrates.

Northern blot analysis was performed to verify differential expression of the Cthsp 70 gene in the E. coli-immunized larvae (Fig. 3). The expression was upregulated $4 \mathrm{~h}$ after $E$. coli injection, reached a maximum after $8 \mathrm{~h}$ and declined gradually after $16 \mathrm{~h}$. These data suggest that HSP70 is involved in the immune response, which is consistent with a previous report that HSP70 expression accompanies immune response in a scallop (Song et al., 2006). Highly conserved heat shock proteins such as HSP70 are known to protect cells against stress by facilitating proper folding of nascent peptides. HSPs have been classified into several families according to their apparent mass, such as HSP90 (85-90 kDa), HSP70 (68-73 kDa), HSP60, HSP47, and low molecular mass HSPs (16-24 kDa) (Tanaka et al., 1988; Morimoto et al., 1990). Heat shock proteins are expressed in response to a wide range of abiotic stressors, but also to biological stressors such as infectious pathogens. Recent data indicate that these stress proteins have the ability to modulate the cellular immune response and play a role in protecting organisms from pathogenic stress (Encomio \& Chu, 2004; Forsyth et al., 1997; Brown et al., 1993: Moseley, 2000; Iwama et al., 1998).

In conclusion, we used dot-blot hybridization to identify some pathogen-induced genes in dung beetle larvae immunized with $E$. coli. A full-length sequence of a dung beetle homolog of $h s p 70$ was determined and found to be up-regulated in larvae in response to infection with the pathogen $E$. coli. 


\section{REFERENCES}

Abe T., Konishi T., Hirano T., Dasai H., Shimizu K. \& Kashimura M. 1995: Possible correlation between DNA damage induced by hydrogen peroxide and translocation of heat shock 70 protein into the nucleus. Biochem. Biophys. Res. Commun. 206: 548-555.

Bischoff V., Vignal C., Duvic B., Boneca I.G., Hoffmann J.A. \& RoYet J. 2006: Downregulation of the Drosophila immune response by peptidoglycan-recognition proteins $\mathrm{SC} 1$ and $\mathrm{SC} 2$. PLoS Pathogens 2: 139-147.

Brown D.C., Bradley B.P. \& Paynter K.T. 1993: The physiological effects of protozoan parasitism on the eastern oyster, Crassostrea virginica: induction of stress proteins. J. Shellfish Res. 12: 135-136.

Bulet P., Hetru C., Dimarce J.L. \& Hoffmann D. 1999: Antimicrobial peptides in insects; structure and function. Dev. Comp. Immunol. 23: 329-344.

Collins A.M., Williams V. \& Evans J.D. 2004: Sperm storage and antioxidative enzyme expression in the honey bee, Apis mellifera. Insect Mol. Biol. 13: 141-146.

Dimarce J.L., Hoffmann D., Meister M., Bulet P., Lanot R., ReichHart J.M. \& HofFmann J.A. 1994: Characterization and transcriptional profiles of a Drosophila gene encoding an insect defensin. Eur. J. Biochem. 221: 201-209.

Enсоміо V.G. \& Chu F.L. 2004: Characterization of heat shock protein expression and induced thermotolerance in P. marinus parasitized eastern oysters: lab and field studies. J. Shellfish Res. 23: 289-290.

ENGSTROM Y. 1999: Induction and regulation of antimicrobial peptides in Drosophila. Dev. Comp. Immunol. 23: 345-358.

Forsyth R.B., Candido E.P.M., Babich S.L. \& Iwama G.K. 1997: Stress protein expression in coho salmon with bacterial kidney disease. J. Aquat. Anim. Health 9: 18-25.

Fukamachi Y., Karasaki Y., Sugiura T., Itoh H., Abe T. \& YAMAMURA K. 1998: Zinc suppresses apoptosis of U937 cells induced by hydrogen peroxide through an increase of the Bcl2/Bax ratio. Biochem. Biophys. Res. Commun. 246: 364-369.

Garcia-Orozco K.D., Lopez-Zavala A.A., Puentes-Camacho D., Calderon-de-la-Barca A.M. \& Sotelo-Mundo R.R. 2005: Recombinant bacterial expression of the lysozyme from the tobacco-hornworm Manduca sexta with activity at low temperatures. Biotechnol. Lett. 15: 1075-1080.

Gething M. \& SAmbrooK J. 1992: Protein folding in the cell. Nature 355: 33-45.

Goodman R. \& Blank M. 1998: Magnetic field stress induces expression of hsp70. Cell Stress Chaper. 3: 79-88.

Hatayama T., Asai Y., Wakatsuki T., Kitamura T. \& Imahara H. 1993: Regulation of hsp70 synthesis induced by cupric sulfate and zinc sulfate in thermotolerant HeLa cells. J. Biol. Chem. 114: 592-597.

HARTL F.U. 1996: Molecular chaperones in cellular protein folding. Nature 381: 571-579.

Hofmann J.A. 1995: Innate immunity. Curr. Opin. Immunol. 7 : 4-10.

Hoffmann J.A. 2003: The immune response of Drosophila. Nature 426: 33-38.

Hoffman J.A., Kafatos F.C., Janeway C.A., Ezekowitz R.A. 1999: Phylogenic perspectives in innate immunity. Science 284: $1313-1318$.
Hultmark D. 2003: Drosophila immunity: paths and patterns. Curr. Opin. Immunol. 15: 12-19.

Iwama GK., Thomas P.T., Forsyth R.B. \& Vijayan M.M. 1998: Heat shock protein expression in fish. Rev. Fish Biol. Fish $\mathbf{8}$ : $35-56$.

Lemaitre B. 2004: The road to toll. Nat. Rev. Immunol. 4: 521-527.

Lindquist S. \& CRaig E.A. 1988: The heat-shock proteins. Annu. Rev. Genet. 22: 631-677.

Maruyama K. \& Sugano S. 1994: Oligo-capping: a simple method to replace the cap structure of eukaryotic mRNAs with oligoribonucleotides. Gene 138: 171-174.

Matsuyama K. \& Natori S. 1988: Molecular cloning of cDNA for Sapecin and unique expression of the sapecin gene during the development of Sarcophaga peregrina. J. Biol. Chem. 263: 17117-17121.

Morimoto R.I., Tissieres A. \& Georgopoulos C. 1990: The stress response, function of proteins, and oersoectives In Morimoto R.I., Tissieres A. \& Georgopoulos D. (eds): Stress Proteins in Biology and Medicine. Cold Spring Harbor Laboratory, New York, pp. 1-36.

Morimoto R.I., Sarge K.D. \& Abravaya K. 1992: Transcriptional regulation of heat shock genes. A paradigm for inducible genomic responses. J. Biol. Chem. 267: 21987-21990.

Moseley P. 2000: Stress proteins and the immune response. Immunopharmacology 48: 299-302.

Sierra-River E., Voorhees G.J. \& Freeman M.L. 1993: Gamma irradiation increases hsp-70 in chinese hamster ovary cells. Rad. Res. 135: 40-45.

Song L., Wu L., Ni D., Chang Y., Xu W. \& XING K. 2006: The cDNA cloning and mRNA expression of heat shock protein 70 gene in the haemocytes of bay scallop (Argopecten irradians, Lamarck 1819) responding to bacteria challenge and naphthalin stress. Fish Shellfish Immunol. 21: 335-345.

Sørensen J.G. \& LoeschcKe V. 2001: Larval crowding in Drosophila melanogaster induces hsp70 expression, and leads to increased adult longevity and adult thermal stress resistance. J. Insect Physiol. 47: 1301-1307.

TANAKA K., JAY G. \& Isselbacher K.J. 1988: Expression of heat-shock and glucose-regulated genes: differential effects of glucose starvation and hypertonicity. Biochim. Biophys. Acta 950: $138-146$.

Thompson G.J., Crozier Y.C. \& Crozier R.H. 2003: Isolation and characterization of a termite transferrin gene up-regulated on infection. Insect Mol. Biol. 12: 1-7.

Wagner M., Hermanns I., Bittinger F. \& Kirkpatrick C.J. 1999: Induction of stress proteins in human endothelial cells by heavy metal ions and heat shock. Am. J. Physiol. 277: L1026-L1033.

Yoshiga T., Hernandez V.P., Fallon A.M. \& Law J.H. 1997: Mosquito transferrin, an acute-phase protein that is upregulated upon infection. Proc. Natl. Acad. Sci. 94: $12337-12342$.

Zhang G., Schmidta O. \& Asgari S. 2006: A calreticulin-like protein from endoparasitoid venom fluid is involved in host hemocyte inactivation. Dev. Comp. Immunol. 30: 756-764.

Received September 3, 2007; revised and accepted December 12, 2007 